\title{
Ezine Yöresel Pazarlarında Satılan Ev Yapımı Tereyağların Mikrobiyolojik Kalitesi
}

\author{
Dilvin IPEK ${ }^{1^{*}}$
}

\section{$\ddot{\mathbf{O z}}$}

Çanakkale-Ezine yöresi süt ve ürünleri üretim kapasitesi yanı sıra içerdiği turistik tarihi alanları ve coğrafi konumu nedeniyle önemli bir bölgedir. Günümüzde dünyada ve ülkemizde doğal beslenme, doğal ürünler ve ev yapımı ürünlerin tüketimi konusunda bir hassasiyet oluşması nedeniyle halk pazarlarında da ev yapımı ürünler tercih edilmektedir. Bu çalışmada Ezine yöre pazarlarında ev yapımı olduğu belirtilerek satılan tereyağların Esherichia coli, koagülaz pozitif Staphylococcus sp ve Salmonella sp. varlığı ile toplam aerobik mezofik bakteri sayıs1, koliform grubu bakteri sayısı ve toplam maya-küf sayısı incelenmiştir. Satışa sunulan tereyağların mikrobiyal kalitesinin Türk Gıda Kodeksi Mikrobiyolojik Kalite Kriterler Tebliğ’inde belirtilen limit değerlere uygun olduğu belirlenmiştir. Bununla birlikte ürünlerin maya-küf yükünün $10^{6} \mathrm{kob} / \mathrm{g}$ seviyesinde olduğu tespit edilmiştir. Ürünlerden izole edilen küflerin mikroskop altında morfolojilerinin incelenmesi sonucu Penicillum, Fusarium, Trichoderma ve Aspergillus sp. gibi mikotoksin üretebilen türlere ait olduğu belirlenmesi ve koagülaz pozitif Staphylococcus sp.'in ürünlerde tespit edilmesi tüketici sağlığı açısından önemli bir risk olarak değerlendirilmiştir. Bu nedenlerle yöresel pazarlarda satılan ev yapımı ürünlerin daha hijyenik şartlarda, kaliteli hammadde ve doğru ısıl işlem uygulamaları ile üretiminin önemi bir kere daha ortaya çıkmıştır.

Anahtar Kelimeler: Ev yapımı, Mikrobiyolojik Kalite, Pazar, Mikotoksin, Enterotoksin, Tereyağı.

\section{Microbiological Quality of Homemade Butters Sold in Ezine Region's Bazaars}

\begin{abstract}
Ezine region has an important dairy production capacity as well as its tourism capacity and location. Todays, people prefer to homemade products in bazaars because of consuming sensivity about natural nutrition, natural products and homemade products in the World and also in Turkey. In this study, we aimed to examine Esherichia coli, coagulase positive Staphylococcus sp., Salmonella sp. presence and total aerobic mesophilic bacteria, coliform and yeast-molds amounts of homemade butters which are sold in region's bazaars. Microbial quality of homemade butter samples were determined within the legal limits in Turkey. However, yeast-molds loads of samples were determined at $10^{6} \mathrm{cfu} / \mathrm{g}$ level. Isolated mold species were identified under microscope with their morphologies as Penicillum, Fusarium, Trichoderma ve Aspergillus sp. which species can produce mycotoxins and coagulase positive Staphylococcus sp. presence was evaluated as an important risk for public health. The importance of healty production conditions, high quality raw materials and optimum heat treatment applications were executed again.
\end{abstract}

Keywords: Homemade, Microbiological Quality, Bazaar, Mycotoxin, Enterotoxin, Butter.

${ }^{1}$ Çanakkale Onsekiz Mart Üniversitesi, Ezine Meslek Yüksekokulu Gıda İşleme Bölümü, Çanakkale, Türkiye, dilvinipek@comu.edu.tr ${ }^{1}$ https://orcid.org/0000-0003-2946-5437 


\section{Giriş}

Türk Gıda Kodeksi Tereyağı, diğer süt esaslı sürülebilir ürünler ve sadeyağ tebliğine göre (2005/19) tereyağ, ağırlıkça \%80-\%90 oranında süt yağı içeren, en fazla \%2 oranında yağsız süt kuru maddesi ve \%16 oranında su içeren ürün olarak tanımlanmıştır (Anonim, 2005). TS 1331 Tereyağ standardına göre ise tereyăg, krema ve yoğurdun tekniğine uygun metot ve aletlerle işlenmesi sonucunda elde edilen, gerekmesi durumunda Gıda Katkı Maddeleri Yönetmeliği’nde izin verilen katkı maddelerinin de katılabildiği kendine has tat, koku ve kıvamdaki bir süt ürünü olarak tanımlanmaktadır (Anonim, 2015). Tereyağ besin değeri açısından insan beslenmesinde önemli bir rolü vardır. Ülkemizde evlerde de üretilebilen bu ürün, halk pazarlarında da satılmaktadır. Günümüzde ev yapımı ürünler oldukça talep görmekte ve sanayide üretilen ürünlere kıyasla daha sağlıklı olduğu algısı halkımızda çok yaygındır.

Tüketim oranı yüksek olan süt ve ürünlerinin kalitesinin halk sağlığını doğrudan etkileyebileceği bilinmektedir (Anonim, 2017). Ürünlerin mikrobiyolojik kalitesi de raf ömrünün yanı sıra ve daha da önemli olarak gıda kaynaklı hastalıklar, zehirlenmeler açısından büyük önem taşımaktadır. Tereyağ ve benzeri sürülebilir süt bazlı ürünlerin (kaymak, krema gibi) mikrobiyal kalitesinin araştırıldığı çalışmalarda toplam aerobik mezofilik bakteri (TAMB), toplam psikrofilik bakteri (TPB), laktik asit bakterileri (LAB), lipolitik ve proteolitik bakteri sayıları yanı sıra maya- küf sayıs1 (MKS), koliform, Esherichia coli (E coli), Pseudomonas sp., Staphylococcus aureus, Listeria monocytogenes, ve Clostridium perfringens yükleri incelendiği tespit edilmiştir. Çalışmalarda patojen bakterilerin özellikle küçük işletmelerde üretilen ürünlerden izole edildiği rapor edilmiştir (Hayaloğlu ve Konar, 2001; Çetin ve ark., 2015; Tomar ve Karaca, 2018). Küf ve mayalar süt mikrobiyotasının önemli unsurlarından olup; düşük 1sıl işlem gören süt, krema gibi ürünlerden tereyağlarda maya-küf yükü kaynaklı gıda bozulmaları görülebilmektedir. Tereyağ örneklerinden patojen Candida sp., Aspergillus, Cladosporium, Fusarium, Penicillum ve Geotrichum sp. gibi maya ve küf türlerinin izole edildiği araştırmalarda bildirilmektedir (Ghasemloy Incheh ve ark, 2017; Moumasher ve ark., 2017; Öztürk ve Çolakoğlu, 2018; Yurdakul ve ark., 2018). Süt ve süt ürünlerinde görülebilen mikroorganizmaların bazılarının enterotoksin ve mikotoksin üreticisi olduğu bilinmekte olup; bu tür toksinlerin halk sağlı̆ıın doğrudan etkilediği bilinmektedir. Aspergillus, Fusarium ve Penicillium küflerinin süt ürünlerinde mikotoksin oluşumuna neden olan önemli küf türlerinden olduğu kabul edilmektedir. Aflatoksin, deoxynivalenol, zearalenone, T-2 toksin, fumonisinler, okratoksin gibi mikotoksinlerin yanı sıra bu ürünlerin üretiminde insan ve hayvan faktörünün bulunması nedeniyle Stafilokokal enterotoksinler tespit edilebilmektedir (Çetin ve ark., 2015; Jovaisiene ve ark., 2016). Enterotoksinler ve mikotoksinler ayrıca 1sıl dirençli oldukları için ürünlerde oluşumu sonrasında 1sıl işlem yolu ile yok edilememektedirler. Enterotoksinler daha çok 
intoksikasyona sebep olurken; mikotoksinlerin ise özellikle gastrointestinal sistem ve karaciğerde kansere sebebiyet verdiği bilinmektedir (Yıldırım ve ark., 2016; Jovaisiene •ve ark., 2016).

Ülkemizde 27/12/2011 tarihli ve 28155 sayılı Resmî Gazete'de yayımlanan ve güncellenen Türk Gıda Kodeksi Mikrobiyolojik Kalite Kriterler Tebliğ’ne göre tereyağ, sürülebilir süt ürünleri ve sade yağ ürünlerinde 5 ürünün 2'sinde $10^{2}-10^{3} \mathrm{kob} / \mathrm{g}$ koagülaz pozitif Staphylococcus sp. (KPS) bulunabilirken, 5 örneğin hiç birinde Salmonella sp. bulunmamalıdır. Yine aynı tebliğ kriterlerine göre çiğ süt ve pastörizasyon sıcaklığından daha düşük sıcaklıklarda ısıl işlem uygulanmış sütten tereyağ ve krema yapıldığında 5 ürünün 2 'sinde $10^{1}-10^{2} \mathrm{kob} / \mathrm{g}$ E.coli varlığına müsaade edilmiştir. Aynı tebliğde, tüketime hazır şarküteri ürünlerinde Stafilokokal enterotoksinin $25 \mathrm{~g}$ üründe bulunmaması gerektiği belirtilmiştir (Anonim, 2011). İlgili tebliğde tereyağ, sürülebilir süt ürünleri ve sade yă̆ ürünlerinde maya-küf sayısı için bir sınır değer belirtilmemiştir.

Çalışmamız sırasında Ezine yöresindeki halk pazarlarında satılan, ev yapımı tereyağların mikrobiyal kalitesi belirlenmiş, Türk Gıda Kodeksi Mikrobiyolojik Kalite Kriterler Tebliğ’ne uygunluğu araştırılmış ve gıda güvenirliği açısından değerlendirilmiştir.

\section{Materyal ve Yöntem}

\subsection{Materyal}

ÇalışmamızdaÇanakkale ilinin Ezine Yöresi olarak adlandırılan Ezine, Bayramiç ve Ayvacık ilçelerinde bulunan halk pazarlarında satışa sunulan 45 ev yapımı tereyağı örneği temin edilmiştir. Örnekler 2019 yılı Şubat-Mayıs aylarında iki farklı zamanda, haftalık olarak iki paralel ve üç tekerrür olacak şekilde analize alınmıştır.

\subsection{Yöntem}

\subsection{1. Örnekleme}

Çalışma sırasında her bir örnek bütünü temsil edebilmesi için yaklaşık $300 \mathrm{~g}$ alınarak steril numune kaplarına koyulmuştur. Örnekler $+4^{\circ} \mathrm{C}$ de laboratuvara getirilerek mikrobiyolojik analize tabi tutulmuştur (Karapınar, 1994; AOAC, 2000). 


\subsubsection{Mikrobiyal Yükün Tespiti}

Tereyağı örneklerindeki toplam aerobik mezofilik bakteri (TAMB) sayısı Plate Count Agar (PCA, Merck 105463, Germany), koliform grubu bakteri ve E.coli sayısı Florocult Violet Red Bile Agar (VRBA+MUG, Merck 1.04030) besiyerlerinin35-37 $\mathrm{C} / 24-48$ saat inkübasyonu sonrasında belirlenmiştir (AOAC, 2000; Harrigan, 1998). Örneklerdeki E.coli varlığı tespit etmek amaciyla besiyeri UV ışı̆̆ının altında incelenmiştir. Örneklerdeki küf-maya sayısı Yeast Extract Glucose Chloramphenicol Agar (YGC, Merck 16000) besiyerinin20-25² C/3-5 gün inkübasyon sonras1 tespit edilmiştir (FDA, 2006).Koagülaz pozitif Staphylococcus sp. (KPS) sayısı Baird-Parker Agar (BPA, Merck 105406) kullanılmıştır. Besi yerinde $35-37^{\circ} C^{\prime}$ de $45-48$ saat inkübasyon sonrasında oluşan, 20200 koloni içeren petrilerde sayım yapılarak tipik görünümdeki koloniler Brain Hearth Infusion (BHI, Merck 113825) Broth'a aktarılmış $35^{\circ} \mathrm{C}$ 'de 18-24 saat inkübasyon sonrasında tüpte koagülaz testi (EDTA'lı koagülaz plazma Merck 113306) yapılarak koagülaz pozitif Staphylococcus sp. sayısı hesaplanmıştır (Ünlütürk ve Turantaş, 2002). Salmonella sp. sayısının belirlemek amacıyla $25 \mathrm{~g}$ örnek, $225 \mathrm{ml}$ Buffered peptone water (BPW, Merck 107228) içine aktarılarak 37² C'de 24 saat inkübasyona bırakılmıştır. İnkübasyon sonunda Selenitine Cystine Broth'a (SCB, Oxoid CM0699) ve Rappaport Vassiliadis Medium'a (RV, Merck 107700) inoküle edilerek SCB'de $35^{\circ} C^{\prime}$ de 24 saat, RV'de $42^{\circ} C^{\prime}$ 'de 24 saat inkübasyona bırakılmıştır. İnkübasyon sonucunda SCB ve RV'de gelişme olan tüplerden Bismute Sulphite Agar (BSA, Merck 105418) ve Brillant Green Agar (BGA, Oxoid CM0329) petrilerine tek koloni düşürecek şekilde çizim yapılarak ekim yapılmıştır. Petriler $35^{\circ} \mathrm{C}$ 'de 24 saat inkübasyona bırakılmış besiyerlerinde gelişen şüpheli tipik Salmonella sp. kolonileri Triple Sugar Iron Agar (TSIA, Oxoid CM0277) ile Lysine Iron Agar (LIA, Oxoid CM0381) besiyerlerine inoküle edilmiştir. $37^{\circ} \mathrm{C}$ 'de 18-24 saat inkübasyon sonrasında gelişme kontrol edilmiştir. Pozitif reaksiyon görülmediğinden daha sonraki aşamalara geçilmemiştir (FDA, 2006; Ünlütürk ve Turantaş, 2002).

\subsubsection{Maya-Küf örneklerinin izolasyonu ve Tanımlanması}

Maya-küf sayısının belirlendiği analizler sonucu elde edilen izolatların saf olma durumları araştırılmıştır. Maya izolatları Potato Dextrose Agar (PDA, Merck 110130)'da çizme yöntemi ile tek düşürüldükten sonra tekrar PDA besiyerine çizilerek stoklanmıştır. Küf izolatları ise göz ile morfolojik olarak incelendikten sonra üç nokta ekim yöntemi ile saflaştırılmış, PDA besiyerine çizilerek stoklanmıştır. Elde edilen saf kültür küf izolatlarının tanımlanabilmesi için laktofenol mavisi ile yaş preparatları hazırlanmıştır. Hazırlanan yaş preparatlar mikroskop altında incelenerek morfolojik yapılarına göre tanımlamaları yapılmıştır (Ünlütürk ve Turantaş, 2002; Pekel ve Korukluoğlu, 2009; Kidd ve ark., 2016). 


\section{Bulgular ve Tartışma}

Çalışma kapsamında Şubat-Mayıs 2019 tarihleri arasında Ayvacık, Bayramiç ve Ezine halk pazarlarından elde edilen ev yapımı tereyağı örneklerinin mikrobiyal yükleri aşağıda verilmiştir (Tablo 1).

Tablo 1. Pazarlardan temin edilen ev yapımı tereyağ örneklerinin mikrobiyal yükleri (logkob/g)

\begin{tabular}{cccccccc}
\hline Pazar & $\mathrm{n}$ & TAMB & $\begin{array}{c}\text { Toplam } \\
\text { Koliform }\end{array}$ & E.coli & KPS & $\begin{array}{c}\text { Salmonella } \\
\text { sp. }\end{array}$ & MKS \\
\hline Ayvacık & 15 & $4,8 \pm 0,03$ & $3,47 \pm 0,06$ & $1,9 \pm 0,08$ & $2,30 \pm 0,18$ & T.E ${ }^{(1)}$ & $6,30 \pm 0,00$ \\
Bayramiç & 15 & $6,5 \pm 0,15$ & $2,00 \pm 0,10$ & $1,82 \pm 0,10$ & $2,30 \pm 0,07$ & T.E & $6,30 \pm 0,04$ \\
Ezine & 15 & $6,17 \pm 0,12$ & $2,47 \pm 0,08$ & $1,87 \pm 0,12$ & $2,78 \pm 0,15$ & T.E & $6,47 \pm 0,21$ \\
\hline
\end{tabular}

(1) T.E: Tespit Edilememiştir

Mikrobiyolojik analizlerde TAMB gıda güvenliği için genel bir hijyen indikatörü olarak değerlendirildiğinden örneklerimizin TAMB sayıları belirlenmiştir. Genel olarak ürünlerin TAMB yüklerinin $10^{4}-10^{6} \mathrm{kob} / \mathrm{g}$ seviyesinde olduğu belirlenmiştir. Ayvacık pazarından elde edilen ev yapımı tereyağ örneklerinin ortalama TAMB sayısı $6,7 \times 10^{4} \mathrm{kob} / \mathrm{g}$ seviyesinde tespit edilirken, Bayramiç ve Ezine ilçeleri pazarlarından alınan örneklerin yükünün $3,1 \times 10^{6}, 1,9 \times 10^{6} \mathrm{kob} / \mathrm{g}$ seviyelerinde olduğu tespit edilmiştir. Hayaloğlu ve Konar (2001) tarafında yapılan çalışmada Malatya ilinde piyasan toplanan, yoğurttan ve kremadan üretilen tereyağ örneklerinin TAMB sayısı yükünün $10^{3}-10^{6}$ ve $10^{4}$ $10^{6} \mathrm{kob} / \mathrm{g}$ arasında olduğu görülmüştür. Araştırmamız sırasında incelenen örnekler genellikle çiğ süt veya süte pastörizasyon sıcaklığının altında ısıl işlem uygulanması sonrası çekilen kremadan üretilmiştir. Hayaloğlu ve Konar (2001) tarafından yapılan çalışmada kremadan elde edilen tereyağ örneklerinin TAMB sayısı $\left(10^{4}-10^{6} \mathrm{kob} / \mathrm{g}\right)$ ile Ezine yöresi pazarlarında sınırlı ısıl işlem sonrası üretilen ev yapımı tereyağ örneklerinin TAMB yükü ile büyük benzer olduğu tespit edilmiştir. Çalışma incelendiğinde tereyağ üretiminde kullanılan kremanın pastörize sütten elde edilip edilmediği hususunda bilgiye ulaşılamamıştır. Karatepe ve Patır (2012) tarafından yapılan bir çalışmada ise Malatya yöresinde faaliyet gösteren bir süt ürünleri işletmesinden alınan tereyağı örneklerine eugenol ve thymol gibi antimikrobiyal maddeler eklenmiş ve son ürünün kimyasal ve mikrobiyolojik kaliteleri üzerindeki etkileri incelenmiştir. Çalışmada herhangi bir antimikrobiyal madde eklenmeyen kontrol tereyağ örneklerinin TAMB sayısı $10^{7} \mathrm{kob} / \mathrm{g}$ olarak tespit edilirken; bu sayının 60 günlük depolama sırasında önemli ölçüde düşmediği görülmüştür. Çalışmamızda ise haftalık olarak üretilen ev yapımı tereyăg örneklerinin TAMB yükü $10^{4}-10^{6} \mathrm{kob} / \mathrm{g}$ arasında olup; işletmede üretilen ürünlerin TAMB yükleri 
ile benzerlik gösterdiği belirlenmiştir.Tereyağı benzeri bir ürün olarak, Tomar ve Akarca (2018) tarafından yapılan çalışmada Afyon ilinde faaliyet gösteren aile işletmelerinden elde edilen kaymak örnekleri ile Ezine yöresinde satışa sunulan tereyağı öneklerinin TAMB sayısı, diğer çalışmalar ile karşılaştırıldığında benzer olduğu görülmüştür $\left(10^{6} \mathrm{kob} / \mathrm{g}\right)$.

Çalışmamızda tereyağ örneklerinin koliform bakteri sayısı yüklerinin genel olarak $10^{2}-10^{3}$ kob/g seviyesinde olduğu belirlenmiştir. Çetin ve ark. (2015) tarafından yapılan çalışmada Kırklareli ili marketlerinden elde edilen tereyağ örneklerinde koliform bakterisi sayısının 3-10 $\mathrm{k}$ kob/g seviyesinde oduğu belirlenmiştir. Ghasemloy Incheh ve ark. (2017) tarafından yapılan çalışmada ise Batı Azerbaycan piyasasında satılan tereyağ örneklerinde bulunan koliform bakteri sayıs $10^{2} \mathrm{kob} / \mathrm{g}$ seviyesinde tespit edilmiştir. Ezine yöresi pazarlarından temin edilen ev yapımı tereyağı örneklerinin koliform sayıları ile Çetin ark. (2015) ve Ghasemloy Incheh ve ark. (2017) tarafından yapılan çalışmalarda belirlenen değerler ile paralel olduğu belirlenmiştir. Çalışmamızla benzer olarak bazı çalışmalarda $10^{1}-10^{4} \mathrm{kob} / \mathrm{g}$ aralığında koliform bakteri sayısı tespit edilmiştir (Idoui ve ark., 2010; Karatepe ve Patır, 2012;Tomar ve Akarca, 2018). Koliform bakteri varlığı üretim ve satış aşamalarında bazı sanitasyon hatalarını işaret edebildiği gibi ev yapımı ürünlerin çiğ süt veya düşük ısıl işleme tabi tutulması nedeniyle görülebileceği yorumu yapılabilir.

Ezine yöresi pazarlarından elde edilen ev yapımı tereyağı örneklerinin E.coli yükleri genel olarak koliform grubu ile benzer olarak $10^{2}-10^{3} \mathrm{kob} / \mathrm{g}$ seviyesinde tespit edilmiştir. Kırklareli ili marketlerinde satılan tereyağı örneklerinin incelendiği bir çalışmada E.coli yükü kolifom bakteri yükü ile benzerlik göstererek 3-10 30 kob/g seviyesinde tespit edilmiştir. Batı Azerbaycan piyasasında satılan tereyağ örneklerinde E.coli yükü 100 kob/g seviyesinde tespit edilmiştir (Ghasemloy Incheh ve ark., 2017). Her iki çalışmada tereyağı örneklerinde belirlenen E.coli yükünün çalışmamızla benzerlik gösterdiği belirlenmiştir. Ülkemizde uygulanan Türk Gıda Kodeksi Mikrobiyolojik Kalite Kriterler Tebliğ' 'ine göre çiğ süt veya pastörizasyon sıcaklığı altında ısıl işleme tabi tutulmuş sütlerden tereyağ yapılması durumunda 5 ürünün 2'sinde $10^{1}-10^{2} \mathrm{kob} / \mathrm{g}$ seviyesinde E.coli varlığına belli bir oranda müsaade edilmektedir. Ezine yöresi pazarlarında satılan ev yapımı tereyağı örneklerinde fekal kontaminasyonun ve shigatoksin riskinin indikatörü olan E.coli varlığının $10^{1} \mathrm{kob} / \mathrm{g}$ seviyesinde belirlenmiştir. Sınır değerler içinde olan E.coli varlığı, ürünlerin pastörizasyon koşulları olmasa bile ısıl işleme tabi tutulduğunu, üreticilerin bulaş konusunda bilinçli yaklaşıma sahip olduğu yorumu yapılabilir. Yine de ev yapımı ürünlerin çiğ süt veya düşük 1sıl işleme tabi tutulan ürünler olması nedeniyle satış koşullarının önemli olduğu düşünülmektedir. Bahar aylarında $10^{1} \mathrm{kob} / \mathrm{g}$ seviyesinde görülen bakterinin sıcaklıkların arttığı yaz aylarında ilgili sınır değerleri aşabileceği göz önünde bulundurulmalıdir. 
Koagülaz Pozitif Stafilakoklar (KPS) açısından örnekler incelendiğinde genel olarak $10^{2} \mathrm{kob} / \mathrm{g}$ seviyesinde bakteri varlığı tespit edilmiştir. Bu değer ülkemiz standartlarına uygun olduğu görülmektedir (5 ürünün 2'sinde $10^{2}-10^{3} \mathrm{kob} / \mathrm{g}$ seviyesinde bulunabilir). Tereyağ örneklerinde Staphylococcus sp. ve S.aureus varlığı üzerine yapılan çalışmalarda $10^{2}-10^{4} \mathrm{kob} / \mathrm{g}$ seviyesinde görülebildiği belirtilmektedir (Ghasemloy Incheh ve ark., 2017; Tomar ve Akarca, 2018). Idoui ve ark. (2010) tarafindan yapılan çalışmada tereyağ örneklerinde Staphylococcus sp., Çetin ve ark. (2015) tarafindan yapılan çalışmada ise S.aureus varlığına rastlanılmadığı belirtilmiştir. Çalışmamızda, yörenin ev yapımı tereyağı örneklerinin üretiminde insan gücü kullanımı ve yetersiz ısıl işlem uygulamaları nedeniyle yapılan çalışmalar ile benzer olarak Staphylococcus sp. varlığı görülmüştür. Ürünlerde $10^{2} \mathrm{kob} / \mathrm{g}$ seviyesinde KPS belirlenmesi, standat değere uygun olmakla beraber enterotoksin varlığı riski bulunduğu dikkate alınması gerektiği düşünülmektedir.

Çalışmamızda hiçbir örnekte Salmonella sp. varlığı tespit edilememiştir. Bu durum daha önceki çalışmalar ile uyum göstermektedir (Çetin ve ark., 2015; Yıldırım ve Bıçakçı, 2018).

Ezine yöresi pazarlarından toplanan ev yapımı tereyağ örneklerinde genel olarak $10^{6} \mathrm{kob} / \mathrm{g}$ seviyesinde maya-küf varlığı tespit edilmiştir. Hayaloğlu ve Konar (2000) tarafından yapılan çalışmada ürünlerin maya-küf yükü $10^{3}-10^{6} \mathrm{kob} / \mathrm{g}$ seviyesinde belirlenirken; Afyonkarahisar ili marketlerinde satılan tereyağı örneklerinde $10^{6} \mathrm{kob} / g$ seviyeinde maya-küf yükü olduğu görülmüştür (Tomar ve Karaca, 2018). Idoui ve ark. (2010) tarafından yapılan çalışmada ise geleneksel Tunus tereyağı örneklerinde $10^{6} \mathrm{kob} / \mathrm{g}$ seviyesinde maya-küf varlığından bahsedilmiştir. Ghasemloy Incheh ve ark. (2017), Azerbaycan marketlerinde satılan tereyağ örneklerinde 102 kob/g seviyesinde maya-küf varlığından bahsederken; Samet-Bali ve ark. (2019) tarafından yapılan çalışmada $4-10^{\circ} \mathrm{C}$ 'de depolanan tereyağı örneklerinde bir hafta süresinde maya-küf yükünün $10^{6}-10^{7}$ kob/g olduğu görülmüştür. Yapılan çalışmalarda tespit edilen maya-küf yükleri ile Ezine yöresi pazarlarından temin edilen ev yapımı tereyağı örneklerinin yüklerinin benzerlik gösterdiği belirlenmiştir.Tereyağlar yöre pazarlarında ambalajsız olarak, açıkta camlı pazar tezgâhlarında satılmaktadır. Bu nedenle ürünlerin maya-küf yüklerinin yüksek olduğu düşünülmektedir. Uygunsuz depolama, taşıma ve satış koşulları mikroorganizmaların ürüne bulaşını kolaylaştırmakta, mikrobiyal yükünün artış göstermesini sağlayacak koşulları desteklemektedir. Ürünlerin satışı açık hava ortamında, sabit bir sıcaklık uygulaması olmaksızın yapıldığından; hava sıcaklığının artması ile kontaminasyon ve mikrobiyal yükün artışı riskinin yükseleceği tahmin edilmektedir.

Çalışmamızda 20 adet küf tereyağ örneklerinden izole edilmiştir. İzole edilen küf izolatlarının 10 tanesinin Penicillum sp., 4 tanesinin Fusarium sp., 2 tanesinin Trichoderma sp. ve 4 tanesinin de Aspergillus sp.'ye ait olduğu belirlenmiştir. Şubat-Mayıs aylarında yapılan çalışmada, elde edilen 20 adet izolatın 7 adeti Şubat-Mart döneminde izole edilebilirken; 13 adeti Nisan-Mayıs aylarında izole edilmiştir. Öztürk ve Çolakoğlu (2018) tarafından yapılan bir çalışmada, Bursa ve Samsun illerinde 
evlerde saklanan tereyağlarda küf varlığı incelenmiştir. Araştırmacılar, çalışmamızla benzer olarak sıcakığın arttığı yaz ayında tereyağ örneklerinden 100 adet küf izole ederken, kış ayında 39 örnek izole etmişlerdir. Elde edilen izolatların \%36'sı Aspergillus sp., \%4,3 Cladosporium sp., \%4,3 Fusarium sp., \%47,5’i Penicillum sp. ve \% 7,9’u ise Fusarium sp. olarak tanımlanmıştır. Süt ürünlerinde toprak kökenli küf türlerinin görüldüğü (özellikle Aspergillus, Fusarium, Penicillium,Cladosporium and Mucor sp.), özellikle küflerin yemlere bulaşı yoluyla küf toksinlerinin tespiti ile ilgili çalışmalar bulunmaktadır (Jovais`iene `ve ark., 2016; Moubasher ve ark., 2018).

\section{Sonuçlar}

Ezine yöresi (Ayvacık, Bayramiç, Ezine) süt ve süt ürünleri üretim kapasitesinin yanında içinde bulundurduğu Assos, Geyikli, Bozcaada ve Kaz Dağları gibi turistik yerler nedeniyle birçok yerli ve yabancı turistlerin de uğrak noktasıdır. Hem yöre halkının hem de yöreye turizm amacıyla gelen insanlar, doğal ürünler konusundaki hassasiyetleri nedeniyle ev yapımı ürünleri tercih etmektedirler. Çalışmada, yöre pazarlarında ev yapımı olduğu belirtilerek satılan tereyağı ürünlerinin mikrobiyal kalitesi incelenmiştir. Örneklemenin Şubat-Mayıs 2019 tarihleri arasında yapılması nedeniyle mikrobiyal yükün hava sıcaklığının en yüksek olduğu yaz aylarına oranla daha düşük tespit edildiği düşünülmektedir. İlgili aylarda alınan örneklerin küf-maya ve TAMB sayıları dışında tüm mikrobiyal yükünün ülkemiz Mikrobiyolojik Kalite KriterlerTebliğ standart değerleri ile uyumlu olduğu tespit edilmiştir. Elde edilen sonuçlar daha önce tereyağların mikrobiyal yükü üzerine yapılan çalışmalar ile benzerlik göstermektedir. Bununla birlikte ürünlerdeki küf-maya sayısının yüksek olması ve izole edilen küf türlerinin mikotoksin üreticisi olabilen türlere ait olması nedeniyle üretim, depolama, taşıma ve özellikle satış şartlarının iyileştirilmesinin insan sağlığı açısından büyük önem taşıdığı ifade edilebilir. Yüksek TAMB sayısı insan sağlığı açısından önemli riskleri, KPS bakterilerin varlığı özellikle enterotoksijenik S.aureus'un ve enterotoksinin ürünlerde bulunabilme olasılığı hakkında bize bilgi sağlamaktadır. Pazarlarda satılan ev yapımı ürünlerin halk sağlığı açısından risk oluşturduğu ve üretim, depolama ve satış şartlarının iyileştirilmesinin gerekliliğinin altı çizilmiştir.

\section{Teşekkür}

$\mathrm{Bu}$ çalışma sırasında örnek alımına ve analizlerin takibi konusunda benden yardımını esirgemeyen Çanakkale Onsekiz Mart Üniversitesi Ezine Meslek Yüksekokulu Süt ve Ürünleri Programı öğrencisi Hacer İrem ADSIZ’a teşekkür etmeyi bir borç biliyorum. 


\section{Kaynaklar}

Anonim, 2005. Türk Gıda Kodeksi: Tereyağı, Diğer Süt Yağ1 Esaslı Sürülebilir Ürünler ve Sadeyağ Tebliği. Resmi Gazete 12.04.2005-25784. Tebliğ No: 2005/19.

Anonim, 2011. Türk Gıda Kodeksi: Mikrobiyolojik Kalite Kriterler Tebliği. Resmi Gazete 27.12.2011-28155. Tebliğ No: 2009/6.

Anonim, 2010. Türk Gıda Kodeksi Mikrobiyolojik Kriterler Tebliğinde Değişiklik Yapılması Hakkında Tebliğ. Resmi Gazete 8.01.2010- 27456. Tebliğ No: 2009/68.

Anonim, 2015. TS 1331 Tereyağ Standard1. TSE-Türk Standartları Enstitüsü, 10s.

Anonim, 2017. Ulusal Süt Konseyi: Türkiye Süt Sektör İstatistikleri Özet Raporu. https://ulusalsutkonseyi.org.tr/wp-content/uploads/Turkiye-S\%C3\%BCt-Sekt\%C3\%B6r\%C3\%BC\%C4\%B0statistikleri-2017.pdf. (Erişim Tarihi 17.08.2019).

AOAC, 2000. Offical Methods of Analysis of AOAC International. Volume I, Volume II 17th Edition, USA.

Çetin, B., Karasu, S., Atik, A., Durak, M. Z., 2015. Investigation of Microbiological Quality of Some Dairy Products in Kirklareli: Detection of Salmonella spp. and Listeria monoctyogenes by Real Time PCR. Journal of Tekirdag Agricultural Faculty. 2015: 12:(1).

FDA, 2006. Bacteriological Analytical Mannual Online. http:// www.cfsan.fda. gov/

Ghasemloy Incheh, K. H., Forouzan, S. H., Hassanzadazar, H., Banafshehchin, E. L., Aminzare, M., Mozafarian, E. L., Hashemi, M., 2017. A survey on the quality of traditional butters produced in West Azerbaijan province, Iran. International Food Research Journal, 24(1), 327-332.

Harrigan, W.F., 1998. Laboratory Methods in Food Microbiology. 3rd edition. Academic Press. London-UK. ISBN 0-12-326043-3. 532p.

Hayaloğlu, A. A., Konar, A., 2001. Malatya yöresinde yoğurttan ve kremadan üretilen tereyağlarının mikrobiyolojik kalitesi üzerinde karşılaştırmalı bir araştırma. GIDA, 26(6).

Karapınar M., 1990. Gıdaların Mikrobiyolojik Kalite Kontrolu. E.Ü. Ege Meslek Yüksekokulu Yayın N:6, 159 S. E.Ü. Basımevi-Bornova-İzmir.

Karatepe, P., Patır, B., 2012. Eugenol ve Thymol'ün Pastörize Tereyağının Kimyasal, Mikrobiyolojik ve Duyusal Kalitesi Üzerine Etkisi. Fırat üniversitesi Sağlık Bilimleri Vet. Dergisi, 26, 35-46.

Kidd, S., Halliday, C. L., Alexiou, H., Ellis, D. H. (2016). Descriptions of medical fungi. $3^{\text {th }}$ Ed. David Ellis. 278 s. ISBN: 9780646951294.

Idoui, T., Benhamada, N., Leghouchi, E., 2010. Microbial quality, physicochemical characteristics and fatty acid composition of a traditional butter produced from cows' milk in East Algeria. Grasas y Aceites, 61(3), 232-236.

Jovaišienè, J., Bakutis, B., Baliukonienè, V., Gerulis, G., 2016. Fusarium and Aspergillus mycotoxins effects on dairy cow health, performance and the efficacy of Anti-Mycotoxin Additive. Polish journal of veterinary sciences, 19(1), 79-87.

Moubasher, A. A., Abdel-Sater, M. A., Soliman, Z. S. M.,2018. Yeasts and filamentous fungi associated with some dairy products in Egypt. Journal de mycologie medicale, 28(1), 76-86.

Öztürk, H. Ö., Çolakoğlu, G., 2018. Bursa Ve Samsun İllerindeki Tereyağlardan İzole Edilen Funguslar Üzerine Araştırmalar. Mantar Dergisi, 9(2), 169-175.

Pekel, M., Korukluoğlu, M., 2009. Sivas Yöresinde Üretilen Küp Peynirinin Mikrobiyolojik, Kimyasal Kalitesi ve Küf Florasinın Belirlenmesi. Anadolu Tarım Bilimleri Dergisi, 24(1), 1-7.

Samet-Bali, O., Ayadi, M. A., Attia, H., 2009. Traditional Tunisian butter: Physicochemical and microbial characteristics and storage stability of the oil fraction. LWT-Food Science and Technology, 42(4), 899905.

Tomar, O., Akarca, G., 2018. Afyonkarahisar'da Satışa Sunulan Afyon Kaymaklarının Mikrobiyolojik Özellikleri. Avrupa Bilim ve Teknoloji Dergisi, (14), 102-109.

Ünlütürk, A. ve Turantaş, F., 2002. Microbiological Analysis of Foods. Meta Basım Matbaacılık Hizmetleri. Bornova-İZMIR.200s.

Williams, R. D. ve Hoagland, R. E. (1982). The effects of naturally occurring phenolic compounds on seed germination. Weed science, 206-212.

Yurdakul, O., Kurdar, S. S., KEYVAN, E., 2019. Detection of Pathogen Candida spp. Isolated from Butter. Mehmet Akif Ersoy Üniversitesi Sağlık Bilimleri Enstitüsü Dergisi, 6(2), 67-71. 